\title{
The effect of rent in urban land and housing value and the building violations in Sanandaj city in Iran
}

Moosa Kamanroodi, PhD.

Kharazmi University of Tehran, Iran

Kamran Jafarpour Ghalehteimouri, PhD Candidate

International Institute of Technology (MJIIT), Malaysia-Japan

\section{Abstract}

Rent is defined as surplus or non-productive profits that are pursued to create naturally (inherited) or fabricated scarcity from a specific product. The value of the land is about the natural and fabricated drivers influence on finalization of the land price and the value of the consumption and trading of urban lands causes "rent" and the unequal profit from the production of housing. Building violations in the city refer to processes for the building and use of which are not licensed (or licensed) or in conflict with the building permit issued by the city hall. This research paper is about the occurrence of building violations, land/housing rent, and the performance of the city hall in this regard in Sanandaj from 2003 to 2011. This research is fundamental and applied research, which has been done by the descriptive-analytical method. Data and information about this research were collected through available documents, reports, and library books, field studies, descriptive statistics, and Pearson Correlation Coefficient were interpreted and analyzed. Based on the findings of this study, out of 8,772 building licenses issued in Sanandaj from 2003 to 2011, 2,886 cases (35.75\%) resulted in 6,291 violations per plot of 20,4294 square meters. The results of this study have shown that land rent and housing, a licensing process and sales of building surplus and city hall earnings have a significant effect on the occurrence had a significant impact on the spatial distribution of building violations in Sanandaj city. The most of the issuance of building permits (98.22\%), sales of the floor area ratio surplus of a building, and building violations occurred in the district 3 of Sanandaj, which enjoyed higher land rent, housing, and a remarkable proportion of the city hall's revenue, was also provided.

Keywords: land and housing rents; land and housing value; building violations; City hall performance, Sanandaj.

\section{Introduction}

The rents, the surplus of a factor of production, is about the amount of revenue of the same factor of production in a competitive situation. The inherent (or natural) difference between the conditions and the value of urban lands has also resulted in unequal rent and unprofitable profits in the production of housing. Urban land rent is 
often due to spatial, physical, ownership, type of land use and management decisions. Building violations in the city are about those changes that do not have a permit which, are not in the building permit or they are against by the city hall regulations. The urban management, with use of planning tools and enforcing the rules different type, the use of land and buildings, results in "renting a difference" in land and the difference in the use value and the value of urban housing exchange. The urban management in big cities in Iran due to loss of revenue from the national government in 1982 has been severely depended on resources, policies, and behaviors. This orientation has led to the sale of an agreement on the surplus floor area ratio of the building and the land use change, land and housing brokers, and the occurrence of building violations in the cities of the country during the 1990s and 2000s.

Though so far, a lot of case studies have been done on informal settlements in other countries (especially developing countries), but the reasons and factors for the occurrence of building violations, especially the impact and relationship of management, rent and housing, and the occurrence of building violations, have paid less attention. There are so limited literature in this regard often addresses the dimensions and a combination of social, economic, technical, and administrative causes of structural misconduct (Alnsour \& Meaton, 2009; Arimah \& Adeagbo, 2000; Fekade, 2000;. loannidis et al., 2009; Kapoor and Belance, 2008; Zegarac, 1999). Among these studies, a case study by Boob and Rao (2012) in India and (Tsing et al., 2008) in Taiwan are also mentioned. Boob and Rao consider the status of compliance with the laws and regulations for the building of residential buildings of two classes $B$ and $C$ in the Yavatmal area of Maharashtra state, which is a developed urban area in India. They concluded in their research that the laws and regulations governing urban development in that area have often neglected. Tsing et al., 2008, with a study of building violations and environmental impacts in Taiwan, pointed out that different solutions to different building violations and its adverse effects should be taken. According to the results of this study, building violations can have effects on public safety, urban landscape, rights and interests of other citizens, urban physical environment, and the other negative impacts. One of the proposed managerial strategies of this research is to increase the costs of committing a violation of the building.

However, significant researches in Iran have been carried out for economic and managerial reasons for the occurrence of building violations. However Raeisdana (2003) introducing a variety of rents and their effects on land, he introduced a new type of rents entitled "Imposed Rents of city Halls" and "Arranged Rents". According to him, this type of rents is handed over by government agencies and city halls through privileges or implementation of restrictions and fines produce a new type of absolute, monopoly rents, and quasi-rents or other kinds of rents. Yazdani (2003) emphasized two important points in the article titled "Generation of rent: the gravity of the city 
hall revenue system": first, urban management by selling floor area ratio has actually caused a structural deviation in the allocation pattern of the economic resources of cities. Second, leverage and the main effective tools for deviations allocating was the granting of permits for urban land and the institutionalization of this phenomenon in the urban structure. Kumaroodi (2005) with the pathology of city hall performance and the occurrence of building violations in Tehran in the 2000s, concluded that the unauthorized sale of surplus floor area ratio and land-use change and monetization of building violations were the most important steps taken by Tehran city management during decade of study. In his opinion, these measures are contrary to the goals of urban development plans in the absence of a comprehensive spatial plan for urban sprawl in Tehran. In addition, it has intensified the occurrence of building violations and instability of the spatial organization of this city. The city hall of Tehran (2010) reviewed the pathology of the building management system in the city of Tehran through the Office of the General Affairs the Commission on Article 100 of the city hall Law in a study entitled "Review and Modification of how to Prevent and Investigate Building Violations". Based on this study, for each building permit issued in Tehran between 1997 and 2008, in the same period about 3.5\% building violations were registered with the Secretariat of the Commission on Article 100 of the city hall Law in this city.

Mohammadi Dastheshmeh and Saeedi (2015) pathological investigation of building violations based on a comparative findings from the metropolitan areas of Iran concluded that, incompatibility of the rules with the realities of the society, the weakness of the monitoring and system control, lack transparency of laws and regulations and, including the factors and barriers to the implementation of the urban development regulations isvery important in building violations. Zangiabadi et al. (2008) in the spatial analysis of the interaction of building violations and earthquake-induced vulnerability in Isfahan regions concluded that with increasing migration, population, housing and building requirements in Isfahan, the number of building violations also increased. Based on this research, most building and building violations occur in the marginal areas of Isfahan city and most of these violations result from the city hall's revenue requirement to fines offenders of the Commission on Article 100 the city hall Law. Mohammadi and Mirzai (2015) have also shown an increase of $0.38 \%$ in the city during the years 2006 to 2012 in explaining the situation and identifying the factors affecting the building violations in the metropolitan areas of Isfahan.

Bahmani Montazeri and Kalantari (2012), investigating the impact of the Commission on Article 100 the City hall Law on the control of building violations in Khoramdreh city, showed that over the past two decades, building violations in that city have increased and the Commission on Article 100 decisions due to incompatibility law and regulations with the facts, weaknesses control and monitoring system, the existence of ambiguous and unclear rules, uncertainties in land tenure, and lack of urban land 
control and city hall revenue approach failed to play an effective role in preventing this phenomenon. Therefore, the most frequent decision to investigate cases of violations of buildingd in the city resulted in the issuing of fines. Pajohan et al. (2014). By analyzing and analyzing the factors affecting buildings violations in Babolsar, the weakness of existing laws and the lack of an effective system for the detection and identification of offenders and the necessary follow-up in this regard by urban management have been identified as the most important reasons for the building violations in this city. Pourmohammadi and Khalilnejad (2002) findings in "studying the role and importance of land in urban development plans and mechanisms for addressing building violations in Tabriz", urban management did not have a systematic program to prevent building violations from occurring until the time the owner's referral does not apply for obtaining a certificate of non-compliance or permitting the split of a city hall facility. According to this study, most of the building violations in the city lead to ask for fines from the owners. Esmaeilpour et al. (2017) investigated the causes of violations of building density in Farkhshahr, which showed that the lack of sustainable revenue, the weakness of the monitoring and control system combined with the high profitability of offenses, the tendency of households to provide housing for their children from the civilian residential complex, and lack of knowledge of the laws is one of the main causes of building violations and administrative barriers to urban planning.

Baharvandi (2012) investigated the causes of building violations in some cities of Lorestan province arise from the lack of awareness of citizens about urban planning regulations, lack of proper information of city halls at the time of issuance of licenses, economic status of citizens, failure to determine the status of land with public use, the lack of public authorities in protecting land and state-owned property and, the incompatibility of the rules with the realities of the community are among the most important factors that are responsible for the building violations in these cities, due to lack of trust and lack of proper supervision by the city halls. Hosseinizadeh Mehrjardi et al., (2013) in analyzing the factors and consequences of unauthorized building in the city of Hamidi showed that the incompatibility of the laws with the realities of society, the severity of the issuance of licenses, the economic benefits of illegal building versus high cost of manufacturing with license, lack of transparency the building regulations, and the inadequacy of the specialist technical department of the city hall are one of the most important reasons for the violations in that city. Sarkhili et al. (2011), in an article entitled "Investigation of the Motivational Violations of the Building of Excess Buildings on Building Concentration in Tehran", the most important factors affecting the occurrence of this type of building offense in this city is the lack of building awareness of building regulations and standards the direct and indirect effect of this violation on the basis of the beta coefficient: 0.616 , the level of revenue (with a coefficient of 0.14 ), and the motivation to meet the family's need through the illegal development of the building (with a coefficient of 0.119). The researchers in another article (2013) 
have shown that the total area of abuse in the metropolitan areas of Tehran with the housing unit, the price of land and building, the ownership coefficient of the vehicle, the average area of land, the average building density and the administrative area of use, the relationship with The confidence level is $99 \%$ and $95 \%$. Rahimi and Panand (2012), in the Notes issued by the Commission on Article 100 the City hall Law building violations in Zahedan district 2, found that these violations are consistent with the development of the city and its building in different parts of the district, indicating that those violations have had a bullish trend, with the increase of factors affecting the land and housing market, the increase in perjury and perpetual buildings and the number of fines has increased.

\section{Study area}

Sanandaj city is located $35 \mathrm{~km} 2$ in the central part of Sanandaj city. The population of this city has increased from 40,641 in 1955 to 373987 in 2012 (Statistical Center of Iran, 1955-2002). The city is divided into 3 districts, 21 zones, and 88 local areas which they represent completely different social, economic and spatial characteristics (Figure 1 and Table 1). District 1, located in the north part of the city, contains the most of the old and urban declined texture and the peripheral tissues of the city. Some of the northern neighborhoods of the district 2 of Sanandaj, which includes the middle part, are part of the old and central texture, and the rest of the neighborhoods have a new urban texture and are considered as new urban neighborhoods. The neighborhoods located in district 3 of Sanandaj, located on the south part, which are new developments.

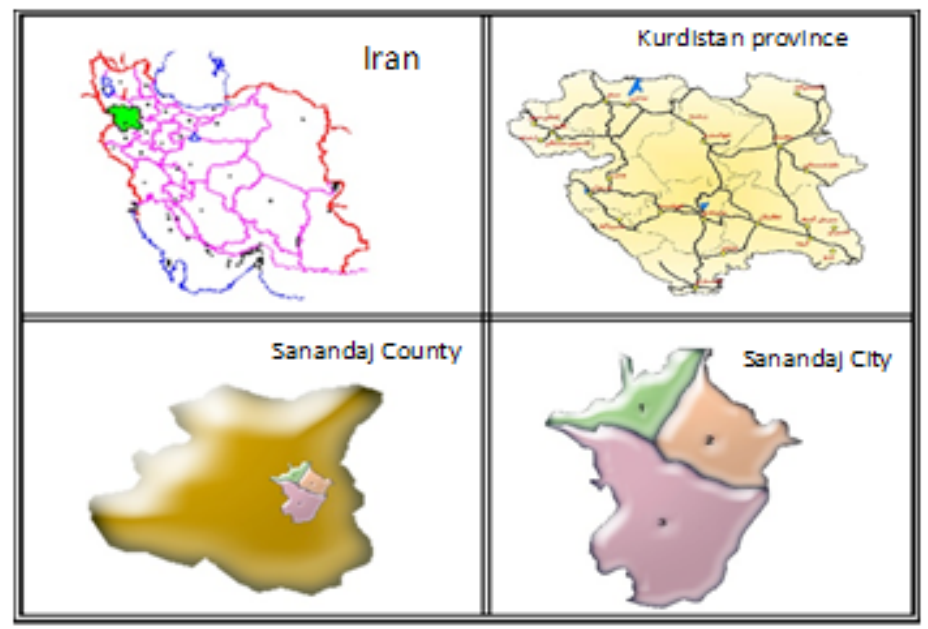

Fig 1: Sanandaj city in Sanandaj county and Kurdistan province 


\section{Theoretical foundations}

Rents in the economic literature mean surplus revenue from the costs of lost opportunity or the surplus of a factor of production relative to the revenue of the same factor of production in full competition conditions. Some economists have defined rents as making money or interest out of unproductive activities. Any factor that makes the competition a monopoly will give rise to rents to one side. This definition is closer to the rhetorical concept of hire, which is the same as a windfall profit or revenue (Miri, 1993). In other words, rents are a kind of surplus or non-productive gain, which is followed by the natural or artificial scarcity of some sources (Khezri, 2005). In Ricardo's view, rents are the part of the land that is given to the landowner in exchange for the use of the inherent and immutable power of the soil. Karl Marx also noted the excessive Ricardian theory of interest. In borrowing Ricardo's theory, he returns to the path to the expansion of class analysis and the dynamics of the capitalist system (Raeisdana, 2001). Adam Smith distinguishes between rents and other sources of revenue, such as wages and profits. In his view, "rents in a different way from wages and profits come from the combination of commodity prices. High or low wages and salaries lead to higher or lower prices, but high or low rents are not the result of high or low prices, but rather be the result. "In this way, it can be seen that rent is revenue that is obtained without effort and opposed to concepts such as wages and profits, which are the result of economic activity and effort (Hajiyosafi, 1997).

The capitalist economy usually introduces land rent as a passive reflection of the "productivity" of capital and labor in different places (Adel, 2001). In Harvey's opinion, in general, the concept of rent in the capitalist economy has been misunderstood with the concept of capital gain. The lack of a distinction between rent and capital returns reflects on theories of how to use urban landscapes. In his opinion, rent is generally part of the value of the exchange that is left as a share of the landowner. The value of consumption means the efficiency and use of an object and the value of an exchange of purchasing power that creates an object for its own. For Harvey, as Marx believed, these two concepts, unlike nineteenth-century economists, are not independent of each other but have a dialectical relationship with each other. In his view, existing analyzes and theories examine the use of urban lands, either solely in terms of value (through the examination of livelihoods) or just the value of the exchange (a market mechanism) (Harvey, 1997). The concept of the rent in theories of urban land use is highly importance (Harvey, 1997). With the growth of the city, the land far away from the city center, and therefore not more prosperous is used, and the difference in the quality of the first and second land leads to the economic rent (only in the first class). In this way, every competition will compete for the location of a place within the city, and the use of any land will be the highest customer. For Ricardo, in a new residential area where the fertile land is high, someone does not pay for rents. Nevertheless, when the 
population tends to rise to second-order land, the first-class land is subject to rents (Mathania, 2000).

According to Von Tunnen (1826), rent increases with increasing distance to the market. The cost of transport in this theory, as the reason for the difference rents in different parts of the land, has replaced the soil fertility variety in Ricardo's theory. Although the difference in economic rents can be due to both factors, Ricardo considers the cost of transporting all land the same and mentions the basis of the difference rents in the difference in fertility and land production. However, Tunnen has the same ability and the basis of the difference Due to the location and location of the land (ibid: 41). Raesidana in his research on urban land rent in Iran introduced a variety of rents and their examples of urban land introduced a new type of rents entitled "Induced Mortgage Rental" or "Rentier Foreclosure" rents. According to him, this type of rents is handed over by government agencies and city halls who, through privileges or implementation of restrictions, fines, and taxes this rent is a type of absolute, exclusive or different kind of rent. In this way, their land can create more produce (more residential units). This is related to their monopoly position as a social level of the capitalist building (or a social class in the Harvey language). Nevertheless, this floor area ratio of a building may be aimed at environments and spaces that can create unique homes (in terms of landscapes and environmental and environmental benefits); then the absolute monopoly or class monopoly (in Harvey's language) is created. However, such aggregate sales companies in Iran can make a richer rendering of rents, which means that if sales of floor area ratio of a building, neighborhoods, areas, or special areas are included, assuming a fixed capital stock composition, this rents forms. When city halls categorize floor area ratio of a building in terms of size according to urban general optimization criteria, they usually share in the rent, in order to get tax, revenue taxes, or wealth, and place it at the city service fund for the benefit of the city. This situation is completely different from the one in which the city hall ignores other criteria and merely attempts to raise revenue in the form of a part of the urban tax. (Raeisdana, 2000). Building violations in the city and its boundaries can be considered as building works that are not permitted or they have not follow the permission by the city hall or other relevant authorities. The violation of the land use change is also related to the change in the type of land and buildings permitted without the consent of the Commission under Article 5 of the Law of the Supreme Council for Urbanism and Architecture of Iran or other relevant legal authorities (Table 1). According to The Commission Article 100 of the city hall law, landowners and real estate located within the boundaries of the city or its boundaries must obtain permission from the city hall before any development or division of land and the start of the building. The city hall can prevent the building of unpermitted buildings or the provisions of the permit by its agents whether the building is enclosed or non-exclusive. According to Note 1 of this Law, in the above cases, which, in terms of the principles of urban technical or 
The Commission on the Article 100 of the city hall demolishing of infrastructures and buildings violation contrary to the specified in the building permission certificate are required without a city hall building permit the demand city hall. The issue is raised in commissions composed of representatives of the Ministry of the Interior, selected by the interior minister and one of the Judges of the Judiciary, elected by the Minister of Justice and a member of the city association to select the city council.

Land and urban housing rent are caused by a variety of factors. Factors can be divided into two general natural and inventive types and intrinsic factors often have a place origin. These factors can cause decrease or increase in intrinsic value of the land. Nevertheless, bogus factors emerge from human structures and functions. These factors usually reduce or increase the inherent advantages of the land. The policies, programs and actions of urban executives are considered as such. Whereas, among all the these factors in land rents and the value of urban housing, the role of political-managerial and legal agents are more important; urban management, using the planning and implementation tools of land use regulations, has caused various types of rent, Rents are different in the city. Therefore, rent is a difference that results from a place in urban space, in addition to natural areas and soil fertility, depends on the decisions and actions of urban management.

\begin{tabular}{|c|l|}
\hline Violation code & \multicolumn{1}{c|}{ Violation description } \\
\hline $\mathbf{1}$ & $\begin{array}{l}\text { Residential building at the floor area ratio in the relevant use (building violation } \\
\text { size at the legal floor area ratio) }\end{array}$ \\
\hline $\mathbf{2}$ & $\begin{array}{l}\text { Residential building surplus on the floor area ratio in the relevant use (building } \\
\text { against excessive Floor area ratio) }\end{array}$ \\
\hline $\mathbf{3}$ & $\begin{array}{l}\text { Nonresidential building Excessive building on the floor area ratio in the relevant } \\
\text { use (commercial, administrative, industrial) }\end{array}$ \\
\hline $\mathbf{4}$ & $\begin{array}{l}\text { Non-Residential building at the concentration capacity in the respective use (in } \\
\text { the permitted capacity range) }\end{array}$ \\
\hline $\mathbf{5}$ & Illegal building in inappropriate land-use \\
\hline $\mathbf{6}$ & $\begin{array}{l}\text { Unauthorized non-residential building in non-authorized use (change of user) } \\
\text { Illegal non-residential building in inappropriate land-use (Land-use change) }\end{array}$ \\
\hline $\mathbf{7}$ & $\begin{array}{l}\text { Unauthorized building based on ratified and official land-use plan in city area } \\
\text { (building of the forbidden building) }\end{array}$ \\
\hline $\mathbf{8}$ & $\begin{array}{l}\text { An unauthorized building contrary to the use approved in the city limits (the } \\
\text { building of a restricted building) }\end{array}$ \\
\hline $\mathbf{9}$ & The building was not released within 25 years of age \\
\hline $\mathbf{1 0}$ & Parking is deducted (changed to a unite) \\
\hline $\mathbf{1 1}$ & Correction in building design \\
\hline $\mathbf{1 2}$ & The Other cases (non-compliance with other urban planning rules) \\
\hline
\end{tabular}

Table 1. Different violation type in the Article Commission of 100 of city hall law Source: The Commission on Article 100 of the Sanadaj city hall 
According to the Note 52 of the total budget law of 1985, the government was allowed to grant credit in row 105004 part four of that law entitled "Ministry of the Interior, to help city halls" at the suggestion of the Ministry of the Interior and the approval of the organization of the plan and budget and the approval of the Council of Ministers distributes between City halls. According to the law, at least half of that credit should be distributed among non-provincial city halls. According to this law, state aid to city halls has been decreasing since 1983, and was very low in the years 1984 to 1989, until it was almost eliminated from 1990 onwards. However, under Section B of the law, the government was required to submit to Parliament within a maximum of six months the city hall self-sufficiency bill, which would represent new financial resources and replace government assistance, in which the country's City hall s would achieve fullfledged full-time planning. However, there were no complaints about this. Hence, since then, revenue from the sale of the floor area ratio of a building and the change of use has formed the main sources of revenue for city hall in the country, including the Sanandaj City Hall.

Considering the literature and theoretical foundations, the conceptual model of this research has been formed from the relationship and interaction of three variables of land price and housing, city hall performance, and building violations. The price of land and housing in different parts of Sanandaj has a different value under the influence of natural, historical, physical, economic, social and managerial factors. These factors are implicitly considered as external and external factors in this research (Fig. 2).
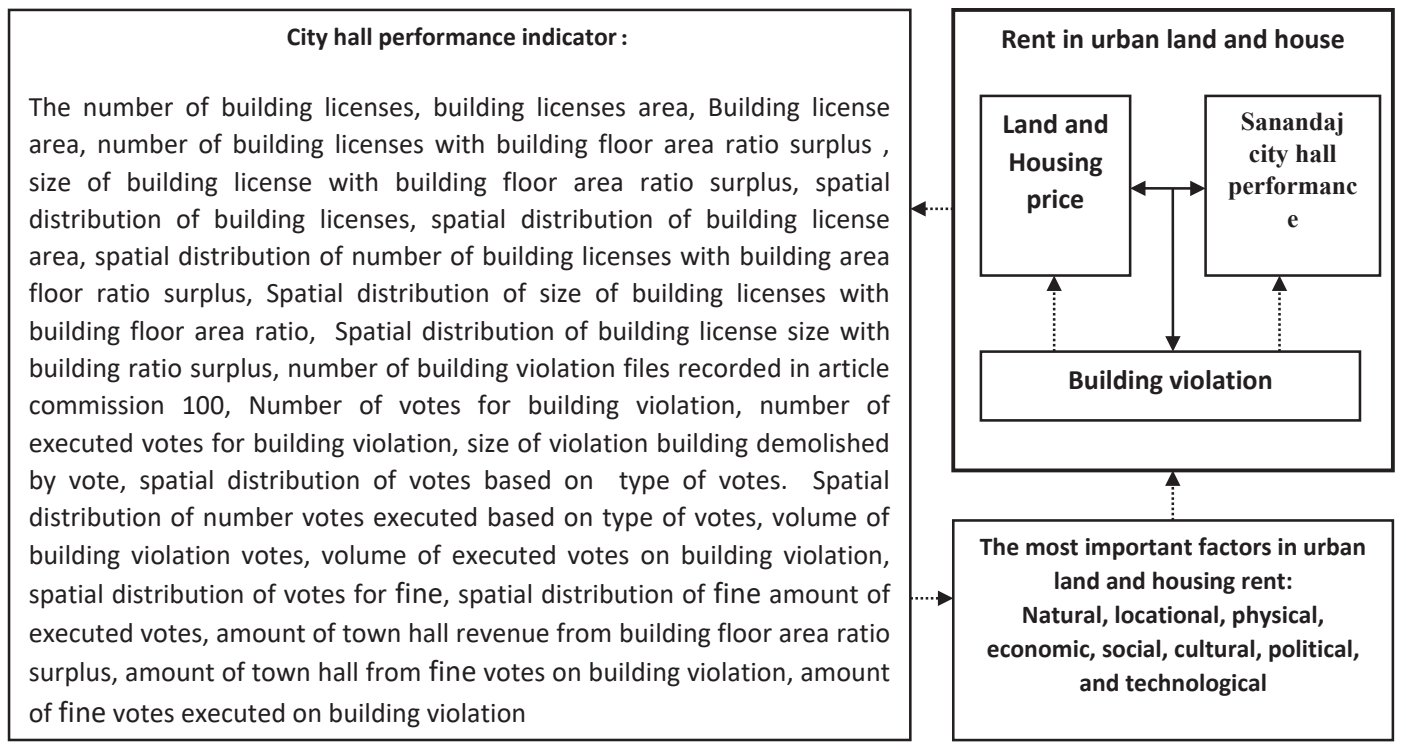

Fig 2. Conceptual model of research "Land Rents and Housing and Building Violations in Sanandaj City from 2002-2013" 


\section{Method and Analysis}

This research is based on the type of fundamental and applied research and in terms of the nature of research type descriptive-analytical. The statistical population of this research is Sanandaj (the capital of Kurdistan province) and its three regions. Data and information of this research were collected through documentary-library and field studies and descriptive statistics and Pearson correlation coefficient were analyzed and analyzed. The average price of land and housing in the city of Sanandaj was obtained by the Delphi method and with the consensus of managers of the offices of real estate consultants located in this city. In this research, the relationship between building violations as dependent variable, land price and housing as independent variable, and city hall performance as a moderator variable in 24 relevant indexes have been investigated. Of course, spatial features are also considered as the variables of land rent and housing value (Table 2).

\begin{tabular}{|c|c|l|c|}
\hline Variable & $\begin{array}{c}\text { Type of } \\
\text { variables }\end{array}$ & \multicolumn{1}{c|}{ Indicators content } \\
\hline $\begin{array}{c}\text { Building } \\
\text { violation }\end{array}$ & Dependent & $\begin{array}{l}\text { The number of documented building violation cases in the Article } 100 \\
\text { commission, The number of building violation, the number of votes for } \\
\text { building violation, the demolition part of building, the size of demolished } \\
\text { area, the spatial distribution of the demolition based on type violation, } \\
\text { spatial distribution of number of the voted to demolish cases, spatial } \\
\text { distribution of performed votes to demolish based on different type } \\
\text { of violation, the number of the crime votes for building violation, the } \\
\text { number of votes for building violation. }\end{array}$ \\
\hline $\begin{array}{c}\text { Land and } \\
\text { house price }\end{array}$ & Independent \\
\hline $\begin{array}{c}\text { Town hall } \\
\text { performance }\end{array}$ & Regulatory & $\begin{array}{l}\text { The number of building licenses, Total building license, The building } \\
\text { license area including surplus floor area ratio, the building license } \\
\text { area including surplus floor area ratio, Spatial distribution of building } \\
\text { license, spatial distribution of building license area, spatial distribution } \\
\text { of building license area with surplus floor area ratio, the amount of } \\
\text { money that city hall made from selling the floor area ratio. Amount of } \\
\text { money made city hall from votes against building violation, the number } \\
\text { of performed votes against the building violation. }\end{array}$ \\
\hline
\end{tabular}

Table 2. Variables and Indices of Research "Land Rents and Housing and Building Violations in Sanandaj City from 2002-2013"

\section{Results and discussions}

The number, size, and building license distribution

According to Table 4, from 2003 to 2013, about 8072 building licenses were issued by the city hall of Sanandaj. Of these 1,365 units of the type of building permit on excess 
floor area ratio 1,878 units of the type of propeller demolition and modernization, and 4869 units of propeller type modernization. The number and density (distribution) of these certificate permits are very different in the three districts of Sanandaj so that 2135 units (26.55\%) of these permits are related to area 1, 2127 units (26.35\%) belong to district 2 And 3810 units (47.20\%) belonged to district 3. Therefore, the abundance of the number building permits in district 3 is much higher than in other districts. $50 \%$ of all modernization permits, $48.8 \%$ of the total destruction and renovation licenses, and $49.81 \%$ of the total number of building permit in Sanandaj city have been allocated to district 3 (Table 3 and Figure 3). However, the number of building licenses for newlybuilt settlements such as Baharan, Villa Shahr, Abyashahr, Zagros and urban areas that are within the services of the city hall of District 3 are not calculated for this study due to lack of access to necessary statistics and information.

\begin{tabular}{|c|l|c|c|c|c|}
\hline \multicolumn{2}{|c|}{$\begin{array}{c}\text { The total number and size for } \\
\text { building license }\end{array}$} & District 1 & District 2 & District 3 & Sum \\
\hline $\begin{array}{c}\text { Building } \\
\text { license }\end{array}$ & $\begin{array}{l}\text { Total issued } \\
\text { certificates }\end{array}$ & 2,135 & 2,127 & 3,810 & 8,072 \\
\cline { 2 - 6 } & Total building licenses & 1,194 & 1,404 & 2,271 & 4,869 \\
\cline { 2 - 6 } & $\begin{array}{l}\text { Total demolish and } \\
\text { renovation building } \\
\text { license }\end{array}$ & 610 & 389 & 879 & 1,878 \\
\cline { 2 - 6 } & $\begin{array}{l}\text { The total number of } \\
\text { the building license } \\
\text { for additional floor }\end{array}$ & 331 & 334 & 660 & 1,325 \\
\hline \multirow{2}{*}{$\begin{array}{c}\text { Building } \\
\text { license size }\end{array}$} & $\begin{array}{l}\text { The total size issued } \\
\text { by building license }\end{array}$ & $2,618,778$ & 689,052 & $183,215,101$ & $186,522,931$ \\
\cline { 2 - 6 } & $\begin{array}{l}\text { The total size building } \\
\text { license }\end{array}$ & 517,868 & 507,243 & $182,677,929$ & $183,703,040$ \\
\cline { 2 - 6 } & $\begin{array}{l}\text { The total renovation } \\
\text { and demolition size }\end{array}$ & $1,999,266$ & 139,480 & 436,919 & $2,575,665$ \\
\cline { 2 - 6 } & $\begin{array}{l}\text { The total surplus floor } \\
\text { area ratio additional } \\
\text { floor }\end{array}$ & 101,644 & 42,329 & 100,253 & 244,226 \\
\hline
\end{tabular}

Table 3. Number and size of Sanandaj city building licenses by type and districts in the period of 2011-2012 Source: deputy of urban planning and architecture of Sanandaj 2013

The total size of the building permit issued by the Sanandaj City hall from 2002 to 2013 was about 186,522,931 square meters, of which $98.22 \%$ were granted to building permits (renovation), $1.38 \%$, plus the forecourt, and $0.13 \%$ thereof It has been dedicated to destruction and modernization. Based on this, $98.22 \%$ of the distribution of the building site of these building permit belongs to the district 3 and the remaining (district 1) 78\% is related to the district 1 and district 2 of Sanandaj (Table 3). Uneven 
distribution of building licenses issued in the three districts of Sanandaj represents the attraction, demand and building boom in the district 3 of this city.

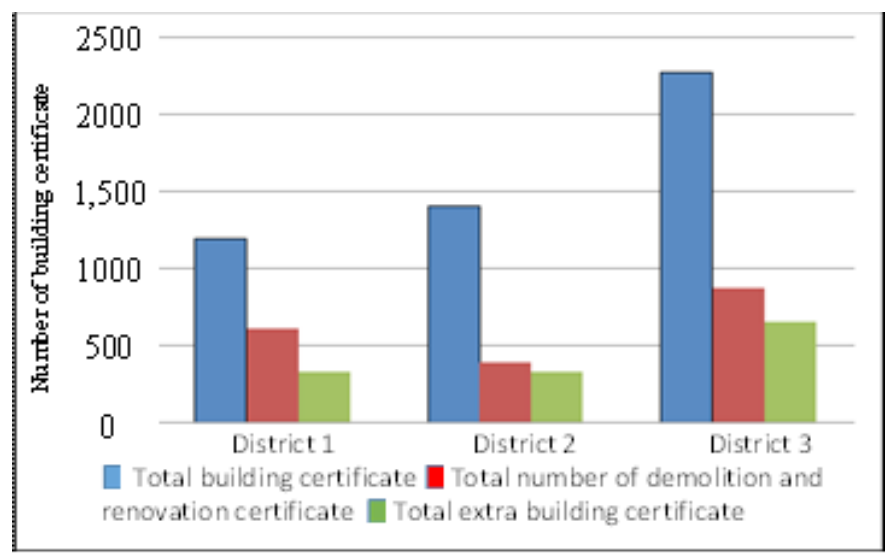

Fig 3. The number of building permits in three district between 2002 and 2013

The number, size and building distribution with floor area ratio of a building surplus

Of the total number of building licenses issued in Sanandaj from 2002 to 2013 (8072 units), 4933 (61.11\%) units contained surplus densities. Distribution of these types of permit certificates among the three areas of Sanandaj has been an incremental trend from district 1 to district 3 . From 2135 building licenses out of total building license issued in district 1, about 104 units (4.87\%), 2127 building permits issued in (district 2) 1019 units (47.99\%), and district 3 not only had the highest number building license issues with 2395 out of 3810 units (62.86\%) placed the highest floor area ratio of a building surplus (Fig. 4). This condition shows the difference between the number of building permits containing overcapacity in the district 3 of Sanandaj in the studied period (Deputy of Urban planning and Architecture Sanandaj city hall, 2013).

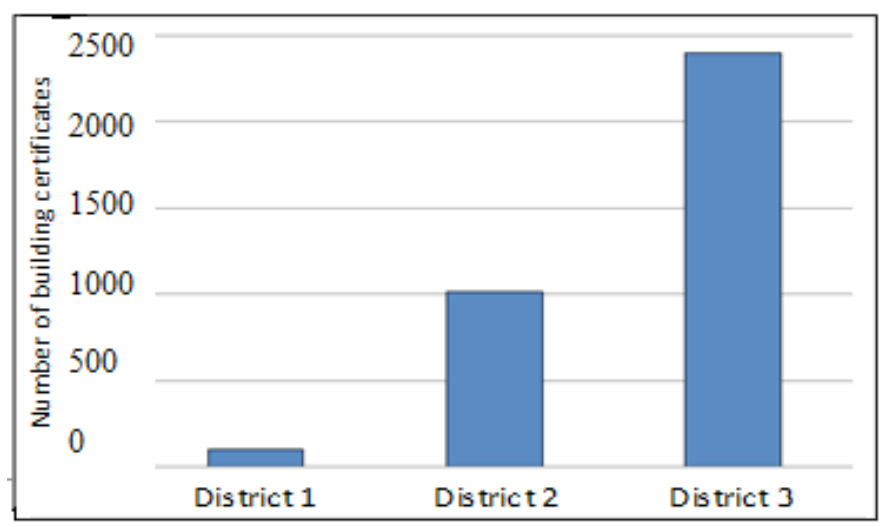

Fig 4: The number of building permit certificates containing the excess floor area ratio in Sanandaj city between 2002 and 2013 


\section{Spatial distribution of number size, and types of building violations}

Of the 8072 building permit issued in Sanandaj from 2002 to 2013, about 2886 permits with a building offense (35.75\%) were submitted to the Commission on Article 100 of the city hall. The number of building permits amounted to about 6,291 violations, meaning that every building license contained an average of 2.17 offenses. District 2 with 577 cases of violations of building (19.69\%) was in the third place, district with 969 cases of building violations (33.57\%) in the second and district 3 with 1340 cases of building violations (46.43\%) in ranked the first. There are 1602 violations (25.46\%) occurred in District 1, 1933 (30.74\%) in District 2, and 2756 (43.8\%) in District 3 out of total 6291 . The total area of building violations committed during this period is about 204,294 square meters (20 hectares), of which 58361 square meters $(28.56 \%$ ) is related to the (district 1) 35052 square meters (17.15\%) of the (district 2) and 110,881 square meters. (54.27\%) was in district 3 (Table 4).

\begin{tabular}{|l|c|c|c|c|}
\hline Certificate number and area & District 1 & District 2 & District 3 & Total \\
\hline $\begin{array}{l}\text { Number of certificates with } \\
\text { building violation }\end{array}$ & 969 & 577 & 1,340 & 2,886 \\
\hline Total building violation & 1,602 & 1,933 & 2,756 & 6,291 \\
\hline Total building violation area & 58,361 & 35,053 & 110,881 & 204,294 \\
\hline
\end{tabular}

Table 4. area and number of building licenses in different district in Sanandaj city between 2002 and 2013

Source: Sanandaj Deputy of urban planning and architecture 2013

On the other hand, the major structural violation investigated by the Sanandaj the Commission on Article 100 of the city hall law was related to the "Residential floor area ratio of Building Surplus" (30/10\%). District 3 has a significant part of the district of abuse for the building of an additional building on population density (code 2). So that $60.65 \%$ of the total floor area ratio of a building on density was related to the district 3 and the lowest was related to the district $2(26.56 \%)$ and district 1 (12.78\%), respectively. After the building of the excess building on the floor area ratio in residential use, the highest rate of violation is related to the violation of the parking lot deficit (code 10). So, from the total number of violations investigated during the years 2002 to 2013, the parking deficit accounted for $27.7 \%$ of the share of offenses. District 1 with a share of 75.7\% (5/201 square meters), district 2 with 29.92\% (606 square meters) and district 3 with $62.32 \%$ (1807 square meters) have a significant difference in this regard (Table 5)

Of these, 259 units (30.66\%) with an area of 17561 square meters (38.53\%) belong to the district of 1 , (190 units $22.51 \%$ ) with an area of 7047 square meters (15.46\%) related to district 2 and 395 units (46/80\%) with an area of 20,961 square meters 
(45/99\%) belong to District 3. Comparison of structural violations of change (code 6) between 2002 and 2013 in the three regions of Sanandaj indicates its significant difference between regions, both in size and in terms of area. district 1 with 312 units (80/33\%) and an area of 586 square meters (90/6\%) ranked first, district 2 with 153 units (57/16\%) cases, code violations (6) and an area of 1906 square meters (22.46\%) was ranked second, and district 3 was ranked first with 458 records (49.62\%) and an area of 5992 square meters (70.62\%).

\begin{tabular}{|c|c|c|c|c|c|}
\hline No. & \begin{tabular}{|l} 
Violation \\
\end{tabular} & District 1 & District 2 & District 3 & Total \\
\hline 1 & $\begin{array}{l}\text { Residential building with certificate with legal floor area ratio } \\
\text { in land-use plan }\end{array}$ & 259 & 190 & 395 & 844 \\
\hline 2 & $\begin{array}{l}\text { Residential building with certificate for surplus floor area } \\
\text { ratio in land-use plan }\end{array}$ & 473 & 258 & 844 & 1575 \\
\hline 3 & $\begin{array}{l}\text { Residential building without certificate with additional floor } \\
\text { area ratio in opponent with land-use plan }\end{array}$ & 266 & 108 & 117 & 491 \\
\hline 4 & $\begin{array}{l}\text { Residential building with certificate and surplus floor area } \\
\text { ratio with land-use plan }\end{array}$ & 330 & 84 & 105 & 519 \\
\hline 5 & $\begin{array}{l}\text { Residential building with certificate and additional floor area } \\
\text { ratio in opponent with land-use plan }\end{array}$ & 13 & 3 & 11 & 27 \\
\hline 6 & $\begin{array}{l}\text { Residential building with certificate with additional floor area } \\
\text { ratio in opponent with land-use plan }\end{array}$ & 17 & 9 & 20 & 46 \\
\hline 7 & $\begin{array}{l}\text { Residential building with certificate with surplus floor area } \\
\text { ratio in opponent with land-use plan }\end{array}$ & 8 & 3 & 6 & 17 \\
\hline 8 & $\begin{array}{l}\text { Residential building without certificate with surplus floor area } \\
\text { ratio in opponent with land-use plan }\end{array}$ & 13 & 4 & 5 & 22 \\
\hline 9 & Building in 25 years restricted area & 0 & 0 & 0 & 0 \\
\hline 10 & Lack of parking & 50 & 193 & 402 & 645 \\
\hline 11 & $\begin{array}{l}\text { Nonresidential building with certificate and with legal floor } \\
\text { area ratio in land use plan }\end{array}$ & 4 & 16 & 6 & 26 \\
\hline 12 & $\begin{array}{l}\text { Nonresidential building with certificate and with surplus floor } \\
\text { area ratio in related land use plan }\end{array}$ & 5 & 17 & 9 & 31 \\
\hline 13 & $\begin{array}{l}\text { Nonresidential building without certificate and with floor } \\
\text { area ratio in related land use plan }\end{array}$ & 4 & 11 & 3 & 18 \\
\hline 14 & $\begin{array}{l}\text { Nonresidential building without certificate and with surplus } \\
\text { floor area ratio in related land use plan }\end{array}$ & 7 & 4 & 2 & 13 \\
\hline 15 & $\begin{array}{l}\text { Nonresidential building with certificate and with floor area } \\
\text { ratio in related land use plan }\end{array}$ & 16 & 18 & 323 & 357 \\
\hline 16 & $\begin{array}{l}\text { Nonresidential building with certificate and with surplus floor } \\
\text { area ratio in opponent land use plan }\end{array}$ & 11 & 16 & 64 & 91 \\
\hline 17 & $\begin{array}{l}\text { Nonresidential building without certificate and with floor } \\
\text { area ratio in opponent land use plan }\end{array}$ & 4 & 19 & 8 & 31 \\
\hline 18 & $\begin{array}{l}\text { Nonresidential building without certificate and with surplus } \\
\text { floor area ratio in opponent land use plan }\end{array}$ & 12 & 15 & 13 & 40 \\
\hline 19 & $\begin{array}{l}\text { Building without permission based on ratified land use plan } \\
\text { in city's boundary }\end{array}$ & 0 & 0 & 0 & 0 \\
\hline 20 & $\begin{array}{l}\text { Building without permission opponent ratified land use plan } \\
\text { in city's boundary }\end{array}$ & 0 & 1 & 0 & 1 \\
\hline 21 & Correction and some additional & 0 & 6 & 0 & 6 \\
\hline 22 & Privacy violation & 15 & 32 & 10 & 57 \\
\hline 23 & Others & 426 & 292 & 649 & 1367 \\
\hline \multicolumn{2}{|r|}{ Total } & 1933 & 1299 & 2992 & 6224 \\
\hline
\end{tabular}

Table 5. Number of building violation in Sanandaj city base on district and violation type between 2002 and 2013.

Source: Sanandaj Deputy of urban planning and architecture 2013 
City hall revenue from floor area ratio of a building surplus and votes on the Commission for Article 100 of the city hall.

As table 6 shows, Sanadaj City Hall made 133,065,250,737 Rails by selling/issuing 4033 building permit between 2002 and 2013. District 3 made 108,562,782,552 Rails $(81.59 \%)$ of Revenue to out total number of issued certificates and revenue, district 2 with 24,328,865,011 million Rials (28.28\%) of Revenues and district 1 with $1,736,037,134$ Million Rials $(0.13 \%)$ of revenue are allocated to Sanandaj from the Commission for Article 100 of the city hall issued approximately 6003 building violations between 2003 and 2013. Of this number, 4638 units (77.26\%) of the unit were fined and 1,365 units $(22.73 \%)$ of the unit related to the destruction vote.

The total number of fine votes, in district 1 about 1476 units of votes (31.82\%) out of total votes, 973 units (20.97\%) votes in district 2 and, 2189 units (47.19\%) votes, in district 3. The total area of the votes fines, 149,521 square meters which 43,052 square meters $(28.79 \%)$ out of total number was belong to district $1,27,912$ square meters (18.66\%) belongs to district 2 and, 78,556 square meters $(52.53 \%)$ belong to district 3 (Table 6 and Figure 5).

\begin{tabular}{|c|c|c|c|c|}
\hline $\begin{array}{c}\text { Number and area of } \\
\text { certificates }\end{array}$ & District 1 & District 2 & District 3 & Total \\
\hline $\begin{array}{c}\text { Number of votes that } \\
\text { issued for fine }\end{array}$ & 1,476 & 973 & 2,189 & 4,638 \\
\hline $\begin{array}{c}\text { Number of votes issues } \\
\text { for demolition }\end{array}$ & 428 & 189 & 748 & 1,365 \\
\hline $\begin{array}{c}\text { Total amount fine made } \\
\text { by votes }\end{array}$ & $6,228,274,925$ & $3,970,599,341$ & $19,160,592,978$ & $29,359,467,244$ \\
\hline fined area issued by vote & 43,052 & 27,912 & 78,559 & 149,523 \\
\hline $\begin{array}{c}\text { Area demolished by } \\
\text { issued votes }\end{array}$ & 899 & 1,202 & 6,907 & 9,008 \\
\hline
\end{tabular}

Table 6. number and area of building license in different districts in Sanandaj city between 2002 and 2013

Source: Deputy of urban planning and architecture Sanandaj 2013

The total amount votes which issued was about $29,359,467,244$ Rials, which is about $21.27 \%$ of this amount out of the total amount is related to district 1 , about $13.52 \%$ belongs to district 2 and $65.26 \%$ belongs to district 3 . The amount of $25,983,214,172$ million Rials (88.5\%) of the total amount of the issued fine has been collected. Meanwhile, the Commission on Article 100 of the city hall Law in Sanandaj issued total of 1365 destruction which is an area equal to 41480 square meters. The study about how and how many destruction cases happened in different districts in Snandaj shows that about $55.66 \%$ of it is in district 3 destruction cases, $32.20 \%$ of it is in district 1 and, $9.13 \%$ of it is in district 2 (Table 6 ). 


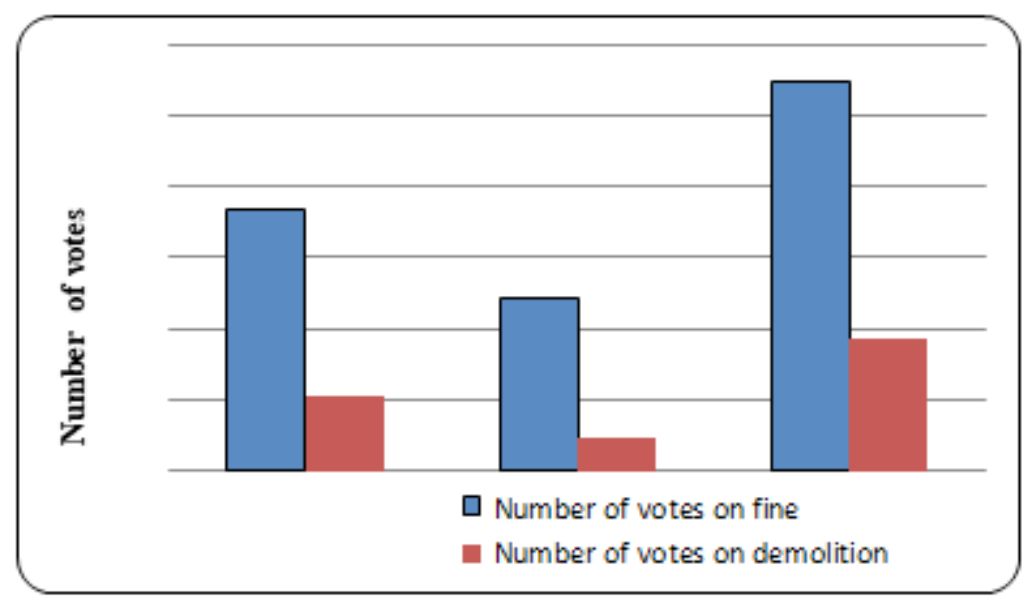

Fig 5. votes on fine and demolition of building violation

\section{Amount and spatial areas of land and housing prices}

Based on Fig. 6, the average price of one square meter of land and housing in Sanandaj in the years 2002 to 2013 was about 4817410 Rials. This amount in district 3 is about 8915520 Rials, in district 2, it is 2989414 Rials and in district 1 is 2547296 Rials. This indicator at the level of district 3 is approximately three times the higher than district 1 and 2.5 times higher than district 2. This difference stems from better location conditions, new township, better infrastructure and facilities, and a higher cultural and economic advantage in district 3 than in the other two regions.

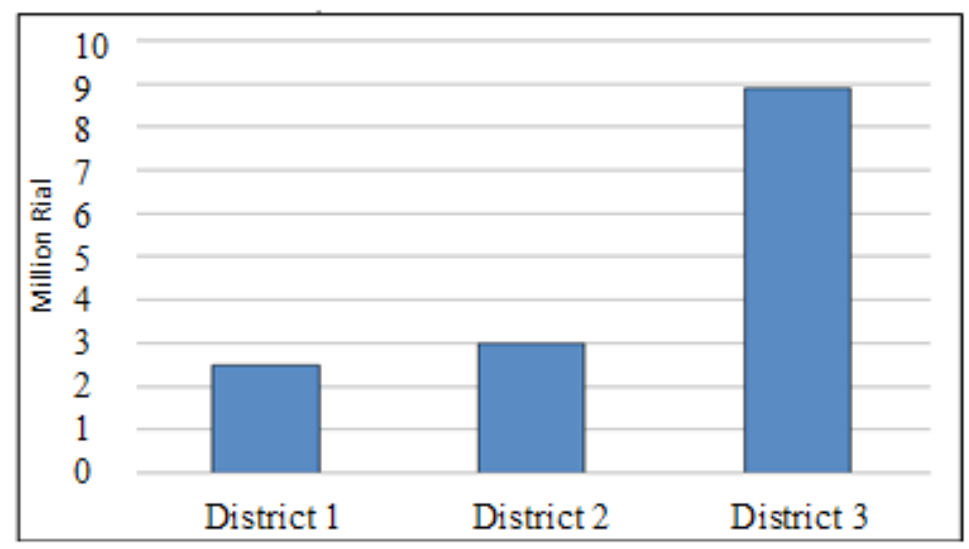

Fig 6. Average land and housing price between 2002 and 2013 


\section{Correlation between building violations, city hall performance, and land and housing price}

In this section, the correlation between the main variables of building violations, land prices and housing, and the performance of the city hall land prices and housing and related indicators have been measured. According to the Pearson Correlation Coefficient, there is a significant correlation between the occurrence of building violations in the three regions of Sanandaj from 2002 to 2013 with most land price indexes and housing and city hall performance. Meanwhile, the total number of building permits issued and the number of licenses with violation, the total number of licenses containing floor area ratio of a building surplus and the number of permits with violation, and the total number of building permit been issued and the total floor area ratio of building violations have a moderate correlation. (Table 7).

\begin{tabular}{|l|c|}
\hline \multicolumn{1}{|c|}{ Variables } & Pearson Correlation \\
\hline $\begin{array}{l}\text { Mean price for per square meters of land and building and total number of issued } \\
\text { building permission certificate. }\end{array}$ & 0.992 \\
\hline $\begin{array}{l}\text { Mean price for per square meters of land and building and total number of issued } \\
\text { building permission certificate with floor area ratio of a building. }\end{array}$ & 0.941 \\
\hline $\begin{array}{l}\text { Mean price for per square meters of land and building and total number of building } \\
\text { violation. }\end{array}$ & 0.976 \\
\hline Mean price for per square meters of land and building and total building violation area. & 0.933 \\
\hline $\begin{array}{l}\text { Mean price for per square meters of land and building and Volume of votes on the } \\
\text { Commission on Article 100 of the city hall Law }\end{array}$ & 0.980 \\
\hline $\begin{array}{l}\text { Total number of issued building license and number of issued building permission } \\
\text { certificate with floor area ratio of a building. }\end{array}$ & 0.975 \\
\hline Total number of issued building license and number of building with violation & 0.749 \\
\hline Total number of issued building license and number of building violation. \\
\hline Total number of issued building license and total building violation area. \\
\hline $\begin{array}{l}\text { Total number of issued building license and total number votes on Commission on Article } \\
100 \text { of the city hall Law }\end{array}$ & 0.995 \\
\hline $\begin{array}{l}\text { Total number of issued building license with floor area ratio of a building and number } \\
\text { certificates with violation. }\end{array}$ & 0.948 \\
\hline $\begin{array}{l}\text { Total number of issued building license with floor area ratio of a building and the number } \\
\text { of building violation. }\end{array}$ & 0.584 \\
\hline $\begin{array}{l}\text { Total number of issued building license with floor area ratio of a building and total } \\
\text { building violation area. }\end{array}$ & 0.992 \\
\hline $\begin{array}{l}\text { Total number of issued building license surplus from what issued in permission and } \\
\text { number of total votes on Commission on Article } 100 \text { of the city hall Law }\end{array}$ & 0.757 \\
\hline $\begin{array}{l}\text { Total number of issued building license with violation and total number of votes on } \\
\text { Commission on Article } 100 \text { of the city hall Law }\end{array}$ & 0.855 \\
\hline $\begin{array}{l}\text { Total number of issued building violation and total number of votes on Commission on } \\
\text { Article } 100 \text { of the city hall Law }\end{array}$ & 0.921 \\
\hline $\begin{array}{l}\text { Total building violation area and total number of votes on Commission on Article 100 of } \\
\text { the city hall Law }\end{array}$ & 0.913 \\
\hline
\end{tabular}

Table 7. Correlation between building violations, city hall performance, and land and housing price 


\section{Summary and Conclusion}

The number 2886 cases and the ratio $35.75 \%$ of the cases of building license license with violation (per capita violation of each case, 2.17 units) referenced to the Commission on Article 100 the city hall Law Sanandaj 2002 to 2013 reflected the fact that the generally the building do not follow the building regulations. The total number of building violations in Sanandaj city during this period was $19.89 \%$ in the district, $33.57 \%$ in the district 1 and $46.43 \%$ in the district 3 . The total area of the violations committed is about 204,294 square meters (20 hectares), which is 58361 square meters ( 28.56 percent) to the district $1,35,052$ square meters ( 17.15 percent) to the district 2 and 110,881 square meters (54.27 percent) Relevant to district 3.

Major and most important building violations in the city of Sanandaj during this period have been allocated to the residential building of surplus (10/30\%). On the other hand, the total area of the building permit issued by the Sanandaj city hall during this period was $1.4 \%$ to the district 1 , district 2 with $0 / 396 \%$ and, $98.22 \%$ in the district 3 . About $61 / 11$ of the building permits mentioned in this period refer to area floor ratio building surplus, and the city hall has received 133,065,250,737 Rials of additional tax from those who made area floor ratio building surplus. District 1 is $87.4 \%$ out of total amount, after that $47.9 \%$ in district 2 and, $62.86 \%$ in district 3 . These conditions derive from the inherent and proprietary relative advantages of district 3 and the rents of land and housing in this district.

The Sanandaj city hall has granted tenant land tenure and housing allowances to landowners and building companies by granting permits for overcapacity in the last decade, and has contributed to the a land and building market which controls by land brokers and dealers. As a consequence of these conditions, each of the factors of production of housing (owners, investors, city halls) who seek the most benefit in parts of the city where the price of land and housing is more valuable, such as change of ownership, area floor ratio surplus and various types of building violations. The spatial meaning of the study of land prices and housing in the city of Sanandaj also suggests that the average price of one square meter of land and housing in the district 3 is three times expensive than that of district 1 and 2.5 times the district 2 . As the average price of one square meter of land and housing in district 3 with an average price of $8,915,520$ Rials, in district 2 with an average price of 2,989,413 Rials, and in the district 1 with an average price of 2,547,296 Rials was in market. This difference in the price of land and housing at the level of the three districts of Sanandaj has caused a correlation between the demand for profitable building and the purchase of excessive city hall floor area ratio of a building and building violations. So, that building activities at the district level have a proportional spatial price for land and housing.

According to the information and implementation of spatial domains of building violations and land and housing prices in Sanandaj, there is a significant relationship 
between these two variables in the city. from 2003 to 2011, out of 6291 violations committed in the area of the city, 1602 violations $(0,466)$ in the district 1, with 1933 cases of building violations $(0,400,030)$ in the district 2 and 2,756 violation of the building (0.0480) occurred in district 3 . Spatial distribution the number of violations committed during the years under review indicates that the proportion between the average spatial distribution of land prices and housing in the regions with the dispersion of the number of building violations has been made. In other words, where land and housing prices are of higher value, the number of building violations, both in number and in terms of area, is greater. Due to the shortage and limitations of land supply, mountain areas and the natural barriers, high elevations and obstacles to the physical development of Sanandaj city, From single story houses to apartment units and city development has changed from vertical to horizontal urban development. These factors have strongly influenced on land market. Building in the floodplains and river banks (around the valley of the valley of the river and the Gheshlagh), extreme changes in the topography, and the balance of the dynamics and land resistance, occupation of public and green spaces lands, the removal of ecological reserves and environmental hazards, including the effects of The land brokers (Farhoodi and Mohammad, 2005). Average 114 hectares of arable lands, gardens and pastures of the city have changed to urban building (Zia Tavana and Ghadarmarzi, 2009).

About $74.50 \%$ of Sanandaj city hall revenue relied on building sector in 2013. These revenues have been include the costs of building permits, excessive floor area ratio of a building, changes in utilization revenue, finess collected by the Commission on Article 100 , offenses for building and civil violations, tolls for removal of parking, balconies and pre-preparedness, renovation and land and building disassembly duties. The composition of resources and the revenue ratio of the Sanandaj city hall indicate that in the event of a recession in the housing sector for any reason, the city hall will face a financial crisis (Table 8).

\begin{tabular}{|c|c|c|c|}
\hline No. & Sources of revenue & Price (million reyals) & Percentage \\
\hline $\mathbf{1}$ & Building license tax & $150,406,283,838$ & $69 / 64$ \\
\hline $\mathbf{2}$ & floor area ratio of a building tax & $23,986,407,781$ & $35 / 10$ \\
\hline $\mathbf{3}$ & landuse change & $9,888,518,708$ & $27 / 4$ \\
\hline $\mathbf{4}$ & Building and urban violatio fines & $14,228,409,513$ & $14 / 6$ \\
\hline $\mathbf{5}$ & Parking change to unite & $4,985,835,140$ & $15 / 2$ \\
\hline $\mathbf{6}$ & Balconey tax & $2,151,149,266$ & $93 / 0$ \\
\hline $\mathbf{7}$ & Renovation & $20,509,488,881$ & $85 / 8$ \\
\hline $\mathbf{8}$ & Tax on land and building separation & $5,641,544,268$ & $43 / 2$ \\
\hline & Total & $\mathbf{2 3 1 , 7 9 7 , 6 3 7 , 3 9 5}$ & $\mathbf{1 0 0}$ \\
\hline
\end{tabular}

Table 8: Sources of revenue in Sanandaj city hall in building sector in 2013 Source: Deputy administrative and finanacial department of Sanandaj City Hall 2013 
According to Pearson correlation coefficient, there is a significant correlation between the occurrence of building violations in the three regions of Sanandaj from 2004 to 2013 with most land and housing price indices and city hall performance. Meanwhile, the total number of building permits license issued and the building licenses with building violation cases, the total number of licenses containing floor area ratio surplus and the number of permits with building violation, and the total number of permit certificates have been issued and the total area of building violations have a moderate correlation.

\section{Bibliography}

1. Alnsour, J.; Meaton, J., 2009. Factors affecting compliance with residential standards in the city of Old Salt, Jordan, Habitat International 33: 301-309. Available at: www.sciencedirect.com (1 Nov., 2009).

2. Arimah, C., \& Adeagbo, D., 2000. Compliance with urban development and planning regulations in Ibadan, Nigeria. Habitat International, 24(3): 279-294. Available at: www.sciencedirect.com (19May, 2009).

3. Baharundi, A., 2013, Investigating the Causes of Construction Violations in Lorestan Province Cities, The First National Conference on Architecture, Restoration, Urbanism and Sustainable Environment. https://www.civilica.com/ Paper-ARUES01-ARUES01_006.html

4. Bahmani, M, H., and Kalantari, M., 2012, Investigating the Impact of Commission Decisions on Article 100 of the city hall on the Control of Construction Misconduct, The 4th Conference on Urban Planning and Management. https:// www.civilica.com/Paper-URBANPLANING04-URBANPLANING04_019.html.

5. Boob, T. N. \& Rao, Y. R. M., 2012, Violation of Building Bye-Laws and Development Control Rules: A Case Study, IOSR Journal of Mechanical and Civil Engineering (IOSR JMCE), ISSN: 2278-1684 Volume 2, Issue 4 (Sep-Oct 2012), PP 48-59.

6. Cheshdehana, F, 2001, Applied Studies of Iran's Development and Economy, Jalalah, Basic Knowledge, Tehran: Nashr-Cheshmeh, First Edition, Tehran.

7. Daci, J. (2012). Protection of the Human Right to Water Under International Law-The Need for a New Legal Framework. Academicus International Scientific Journal, 3(06), 71-77.

8. Edel, M. Urban and Regional Economics: Marxist perspectives. Taylor \& Francis, 2013. Persian Translation by Fariborz Raisedana, First Edition, Publisher Khaneh Ghatreh, Tehran. 
9. Esmailpour, N, Dehghan D., E, and Khakian Dehkordi, M, 2016, Causes of violations of building in cities of Iran with an emphasis on building density and providing solutions to reduce it (Case study: Farakhshahr), International Conference on Engineering Sciences, Arts and Law. ttps://www.civilica.com/ Paper-ICESAL01-ICESAL01_071.html. COI Journal ICESAL01_071

10. Farhoudi, R and Amikchi, A, 2005, Historical development, land use and urban planning bottlenecks in Sanandaj, Journal of Geographical Research, No. 53, pp. 98-87.

11. Fekade, W., 2000. Deficits of formal urban land management and informal responses under rapid urban growth: an international perspective. Habitat International, 24(2): 127-150. Available at: www.sciencedirect.com (13Mar, 2009).

12. Hajiyosofi, A, 1997, Rents, Renter's Government and Rationalism: A Conceptual Review, Journal of Political-Economic Information, No. 125 and 126, pp. 155152. http://ensani.ir/file/download/article/20101210130307-755.pdf

13. Harvey, D, 1997, Social Justice and the City, Translated by Farrokh Hesamian, Mohammad Reza Haeri and Behrouz Monadizadeh, First Edition, Publication of Urban Planning and Processing Co., Tehran.

14. Hosseinizadeh M,S., and Mirnezhad, S. A., 2015, An analysis of the factors and consequences of unauthorized construction in the city of Hamidia and its solutions, the first National Conference on Civil Engineering, Architecture and Sustainable Development. https://www.civilica.com/Paper-CEASD01CEASD01_054.html.

15. Ioannidis, Ch., Psaltis, Ch., Potsiou, Ch., 2009. Towards a strategy for control of suburban informal buildings through automatic change detection, Computers, Environment and Urban Systems 33:64-74. Available at: www.sciencedirect. com (14Nov, 2009).

16. Iovan, M. (2014). Eco-education: A required element of public policies for sustainable social and economic development. Academicus International Scientific Journal, (09), 14-28.

17. Khezri, M., 2005, Rent Economics: A Review of the Rendering Areas in the Public Budgeting System of Iran, First Edition, Publications of Management and Planning Organization, Tehran. https://www.sid.ir/fa/journal/ViewPaper. aspx?id=101789

18. Kamranoudi, M, 2017, Structural violations and physical-spatial changes in Tehran metropolitan areas, Quarterly Journal of Environmental Spatial Analysis, First Year, Serial No. 2, Pages 76-65.

19. Kamranoudi, M, 2005, Structural Barriers to Urban Development Management in Iran, Political Economy Quarterly. Third Year, No. Ten, pp. 57-48. 
20. Meadari, A, 1993, Asymmetry of Source Information Rents, Strategic Quarterly, No. 4, pp. 62-43.

21. Mertania, M, 2000, Economic Rents (Ownership Interest) in Urban Development Plans, Urban Management Quarterly, First Year, No. 1, pp. 48-40.

22. Mohagheh, $M$, Darabkhani, R, Jafari, E, and Zinelzadeh, A, 2014, An Investigation and Analysis of the Factors Affecting Structural Infringements in Small Towns (Case Study: Babolsar City), Quarterly Journal of Urban Planning Geography, Vol. 2, No. 2, Pp. 252-239.

23. Mohammadi, J and Mirzaie, S, 2016, Explaining the Situation and Recognizing the Factors Affecting Building Violations in Iran's Metropolises Case Study: Isfahan's Fifteen Areas, Geographic Survey Quarterly, Year 30, Issue 2, Serial No. 1, Pages 214- 195

24. Mohammadi Dakhshmeh, M and Saidi, J, 2015, Pathology of violations of the subject matter of Article 100 of the city hall Law, based on comparative findings from Iran's metropolises, Journal of Legal Science and Research, Vol. 3, No. 1, Pages 168-139.

25. Musaraj, A. (2011). Albania, the human factor and sustainable development: a lesson from the present. Academicus International Scientific Journal, 2(04), 35-41.

26. Pong-Kuang Tseng, Che-Ming Chiang, Hsueh-Yen Hu, \& Chau-Yau Chen, 2008, Categories of Building Violations and Environmental Externalities-Empirical Observation in Taiwan, http://www.prres.net/ index.htm?http://www.prres. net/Proceedings/2009proceedings.asp.

27. Pourmohammadi, M., and Khalilnejad, A., 2002. The role and importance of land in urban development projects and the mechanisms for dealing with construction violations (Case study: Tabriz city), Geography and Planning (Journal of the Faculty of Humanities and Social Sciences, Tabriz University), No. 30, pp. 32-9. https://www.magiran.com/p1820588

28. Raeisdana, F, 2003, introducing a new species of urban land rent, Office of Cultural Research, Quarterly Journal of Political Economy, No. II, pp. 118-109.

29. Rahimi, Vahid and Panand, Abdolsamad, 2014, Analysis and review of the Commission's opinion on Article 100 of the city hall -Case study: District 2 of the Zahedan city hall, Fourth Student Conference on Geography. https://www. civilica.com/Paper-IGSCUT04-IGSCUT04_067.html

30. Sorkhili, E, Rafiean, M, and Bomanian, M, 2012, Investigation of the Motivations of Violation of Building of Surplus Building on Building Density in Tehran, Urban Management Quarterly, No. 30, pp. 162-145. 
31. Sorkhili, E, Rafiean, M, and Bomanian, M, 2014, Investigation of the relationship between building violations of Tehran's spatial change and structure using spatial regression analysis, Journal of Architecture and Urban Development, Vol. 6, No. 12, Pages 41-23.

32. Tehran city hall, 2010, Revision and modification of how to prevent and deal with the building of a building, Research Report: Summary Report.

33. Yazdani, F, 2002, Financial Management of the City: Rent Production, Grants of the cityl Revenue System, Urban Management Quarterly, No. 13, pp. 17-12.

34. Zangi Abadi, A, Ghadeghmati, Z, Mohammadi, J, and Safaii, H, 2010, Spatial Analysis of Interaction of Building Violations and Earthquake-Based Vulnerability: Isfahan Townships, Quarterly Journal of Planning and Space Design, Vol. 14, No. 2, Pages 1- 21

35. Zegarac, Z., 1999. Illegal building in Belgrade and the prospects for urban development planning. Cities, 16(5): 365-370. Available at: www.sciencedirect. com (11 Oct., 2009).

36. Ziavanaha, Mo and Ghadarmarzi, H, 2009, Land use changes in Pira Shahri villages in the urban creep process of the villages of Naysar and Hassanabad, Sanandaj. Quarterly journal of human geography, no. 68, pp. 135-119. 